\title{
The Impact of the European Financial Integration Process and Other International Tendencies on the Romanian Stock Market
}

\author{
Alina Camelia Sargu, Alexandru Ioan Cuza University, Iaşi, Romania
}

\begin{abstract}
The study presents in a comprehensive way the effects that deregulation, internationalisation, integration, financial innovation and the development of the institutional investors have had on the Romanian stock market. Using dates provided by several relevant sources on the field, like the Bucharest Stock Exchange or Intercapital, we have established in which extent these tendencies emerged on the Romanian stock market and if our stock market has already reached the point where it will be able to fully integrate itself in the European financial system.
\end{abstract}

\section{Keywords}

Financial integration, deregulation, internationalisation, financial innovation, institutional investors

Jel Code: G10, F15, F21, F36, N24, O16

\section{Introduction}

In the last decade, the global financial system has considerable evolved and matured. All over the world, markets developed and became more liquid, while in the same time crossborder investment has registered a sharp increase, especially towards the emerging markets of the world. These facts have lead to the increase of the stock markets integration process, which is especially visible in the European Union.

The integration of the European stock markets has been a very dynamic and complex process, emerging on all markets, including the Romanian one. Other main European tendencies that have emerged on the Romanian stock market are represented by: the process of deregulation, the internationalisation of the national stock markets, the financial innovation, doubled by the development of the institutional investors. Thus, even if it is far from being a well developed stock market, the international trends that exist on the mature stock markets, like London or Paris, are already emerging on the Romanian one.

\section{Methodological Considerations}

As financial dates are becoming more available, the researchers have the opportunity to examine more in depth aspects of European financial integration, like cross-boarders investments and their impact on financial integration ${ }^{1}$. After an extended literature review we have concluded that these researches tend to underline the idea that financial integration among euro zone countries is fair higher when compared with the other European Union member states. The most recent studies reviewed argue that the difference is anywhere

\footnotetext{
1 Lane, P.R. (2008), EMU and Financial Integration, in: The Euro at Ten: 5th European Central Banking Conference, Lucrezia Reichlin, Ed. ECB, Brussels, pp. 12;

2 e.g. Ekinki, Kalemli-Ozcan, and Sorensen 2008; Portes and Rey 2005; Guiso, Sapienza, and Zingales 2009
} 
between $200-300 \%$, which may seem a little bit unrealistic. This is happening because the time spam that the research covers is to short, and this is forcing a more direct method of research, like a cross-sectional approach, that compare integration on a pair of countries rather than a whole area. Using this method we cannot account for time-invariant factors like geographical distances, cultural ties or trust, that are having a determinate effect on the whole integration process ${ }^{2}$. Beside this, the lack of clear dates regarding the before and after period of European ascension, there is hard to separate the integration effect from other factors, like reform or global trends (in this way we might have a reasonable explanation for the inflated figures above). But the bottom line is that even if acknowledged these limitations, because of the confusing nature of these factors, we do not have a clear view over the impact of the European financial integration process.

In this regard, our methodological approach was more qualitative, establishing the main trend from the developed stock markets and underling their overall impact on the Romanian stock market. We have used in our analyses raw dates provided by the Bucharest Stock Exchange underlying directly the shifts that have occurred in the volume of transaction and capitalisation of the Exchange, as a result of Romanian integration into the European Union. The volatility of the stock markets was calculated as standard deviation of daily returns.

\section{The Implications of the European Financial Integration Process on the Development of the Romanian Stock Market}

The key for obtaining a sustainable economic growth in the European Union, making it more efficient and competitive, is represented by the integration of the financial sector. The single market for European financial products and services will have an important contribution to the increasing of the European Union economy as a whole. For example, if the financial integration of the European Union will lead to the same level of development in the financial sector as in the United States, the net growth of the real economy of the EU will be stimulate directly with more than one percent every year ${ }^{3}$.

For Romania, the integration in the European Union from 1st of January 2007 marked the enhancement of the integration process of the financial sector. Foreign investors tend now to invest more in Romania as a result of better guarantees regarding their property right and also because of the fact that Romania, as part of the European Union, has implemented also the European financial passport. We must also acknowledge the fact that the Romanian stock market has become more exposed to systemic risks, as a result of the European integration process. The domino effect that emerged in all of the European Union member countries, as a result of the financial crises started in 2007, had a catastrophically effect on the Romanian stock market.

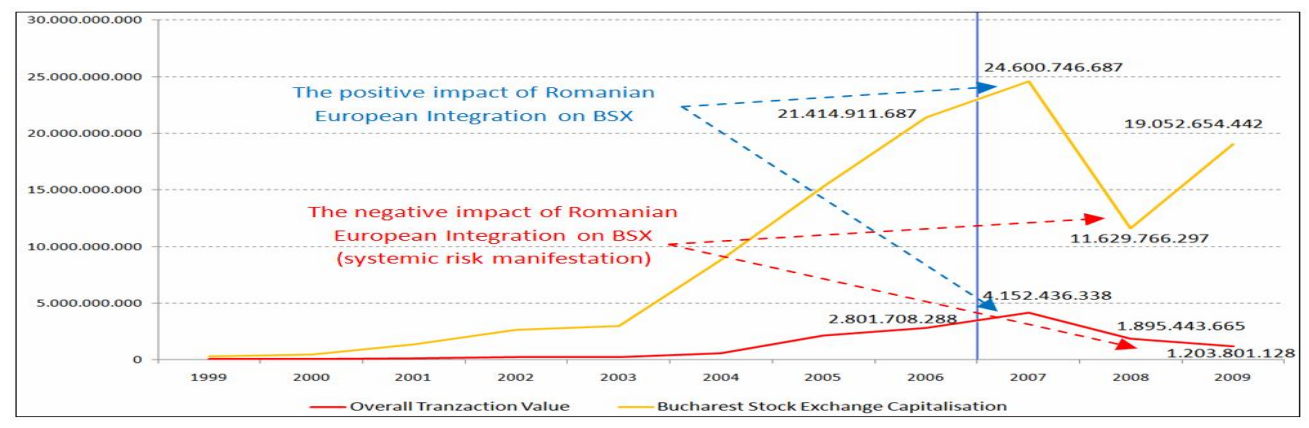

3 Liebscher K., Christl J., Mooslechner P., Ritzberger-Grünwald D. (2006), Financial Development, Integration and Stability - Evidence from Central, Eastern and South-Eastern Europe, Cheltenham, United Kingdom, pp.21 


\section{Figure. 1. The Evolution of the Overall Transactions Value and Capitalisation at the Bucharest Stock Exchange Between 1999 and 2009 (EUR) \\ Source: own simulation based on the dates provided by the Bucharest Stock Exchange}

It is obvious that after the integration in the European Union, on the $1^{\text {st }}$ of January 2007, the Bucharest Stock Exchange registered an important raise both in the overall transactions value (with an increase in value of 48\% compared to 2006) and in the value of its capitalisation (with a raise of 14\% compared to 2006). Even if we cannot attribute the whole raise in value to the integration process, it is more than obvious that this event played a catalytically role.

Even if the integration of the Romanian stock market has been a stimulating factor for its development, its gains must be enhanced by its future evolution. Taking this into consideration, the BSX has three options regarding its sustainable development:

To continue its activity as an independent market- in this sense the BSX must lunch new financial instruments, as a result of financial innovation, in order to attract new and sophisticated investors and so to raise its assets. In order to survive it must also cut down its cost and increase its revenues. Regarding cost cuts, BSX could implement another's stock exchange software solution, if it will mean a more optimal way of handling business, both from a cost and managerial point of view, rather continuously developing and updating its own software solution.

To initiate an alliance or a merger with another similar in size stock exchange from the region - in this regard the BSX is already having collaborations with the stock exchanges from Vienna and Salonika and also with other stock exchanges from around the globe, meant to increase its liquidity and reduce its costs. Unfortunately these collaboration are rather more formal that functional operations. A good example in this case is the collaboration with the Salonika Stock Exchange, which was signed at the end of 2003 and aimed at the development of a dedicated market segment entitled „new market”, which was supposed to handle small and medium size enterprises (SMEs). Unfortunately not even today this segment hasn't become operational. In the same sense, because of the formal and minimal collaboration that existed so far, the agreement with the Vienna Stock Exchange hasn't provided the anticipated international exposure and hype, that such an active partnership will had have granted on the more underexposed market.

To merge or to forge an alliance with a developed stock market - until now only OMX has expressed a direct interest in acquiring BSX, as other major stock market from Europe are more interested in partnerships with other major stock market and only have a side interest in acquiring smaller exchanges. The OMX offer has come as part of a broader approach that the Nordic stock exchange has on Eastern Europe. Its strategy aimed at implementing its own transaction platform, creating in this way the premises of attracting a larger number of investors from this region to its products. In practice the stock exchanges will have had remained separate entities, but for the investor the companies will have had appeared on his transaction screen as if they were listed all on the same market. At this point the BSX is using is very own ,in house brewed" transactional software entitled Arena. The integration of the companies listed on all the exchanges on the same platform will have had raised the exposure of the companies from the smaller and underexposed markets, making them more visible for the international institutional investors. In this perspective BSX had only to lose from its refusal to join OMX in this partnership. Taking in to consideration only the opinion of the board of directors of BSX, the refusal had denied the BSX access to the main two trumps of OMX - experience and technology.

Regardless of the path that BSX will choose, in the future, the main characteristic of its development will be cooperation, especially in the context of Romania's ascension to the European Union and the deepening of the convergence process, as a result of the preparation for the future transition to the EURO. For now, BSX continues to follow closely the trends of 
the major European stock markets, pursuing its own "organic" development, which will allow it to obtain the maximum benefits from a future possible alliance or merger.

\section{Deregulation, Reregulation and the Impact of Financial Innovation on the Romanian Stock Market}

At the end of the eight decade of the past century, the stock markets have been hit by a wave of deregulation which included the loosening of the supervision and control regimes. The aim of these changes was to enhance competition and to raise the efficiency of the stock market in general. The Big-Bag of the London Stock Exchange in 1986 followed by the Big Bang of the France stock market in January 1988 and that of the Belgium stock market in 1989 have no parallel in the Romanian economy since in that period the Romanian stock market didn't even exist. Even if it was lunched much later, in 1995, the Romanian stock market has been affected by these changes. A good example in this case is the privatisation of the Romanian Stock Market in 2005, which was transformed in an incorporated company (the shares of the new company being equally split between the financial services companies that were active on that date on the market). The only ones who are allowed to own shares at the Romanian Stock Market are the financial services companies. Private persons, firms or even institutional investors are forbidden to own a share in the entity. This is the opposite of the situation on other stock markets like Deutche Borsa were almost $97 \%$ of the shares of the stock market are owed by institutional investors, the rest being in the possession of private persons. Each stock market has its own policy regarding the management of its shares and the way they are traded. Most of the developed stock markets are public companies, often being traded on their own floor. The Bucharest Stock Exchange is also considering such an approach.

Another tendency present on most of the developed stock markets, which is also a result of the deregulation process, is the constant innovation of financial services. Probably the most known financial innovation which is becoming available also on the Bucharest Stock Exchange is represented by derivates as means to diminish the risk allocated to transactions. In the developed countries these products have a long standing tradition, being highly appreciated by investors. Chicago is the main market in the world with regard to derivates, a proving fact being the inauguration of the Chicago Board of Trade in $1970^{4}$.

To underline the rapid development of this sector we must also take into consideration the development of such products and the beginning of trade at the Bucharest Stock Exchange starting from 2007.

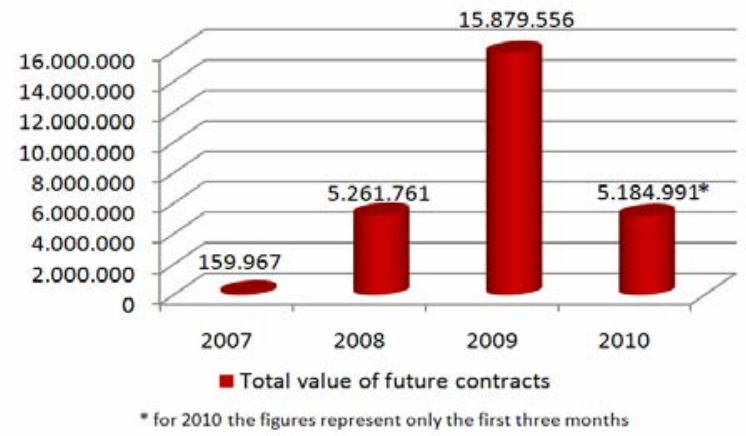

Figure. 2 - The Development of the Future Contracts Market From the Bucharest Stock Exchange Between 2007 and March 2010 (Total Value of Future Contracts EUR)

\footnotetext{
${ }^{4}$ Gaftoniuc, Simona (2000), International finances, Economic Publishing House, Bucharest, pp. 380
} 
Source: own simulation based on the dates provided by Romanian Business Digest

As we can observe, all the values of the indicators of the future contracts market from the Bucharest Stock Exchange are much higher in 2009 when compared to 2008 or 2007, which shows that this sector is developing fast.

Besides the aspects presented regarding the effects of the deregulation process on the Bucharest Stock Exchange, we must also take into consideration the regulation of the Romanian stock market. The Romanian Stock market is regulated through the 297/2004 Law regarding the stock market and its activities, which was developed in concordance with the European directives in the field, taking into account a possible merger or acquisition of the Bucharest Stock Exchange by a larger European counterpart ${ }^{5}$.

In the current economic context, were the systemic risk has emerged especially on the more deregulated stock markets, there is a large debate about re-regulation with regard to the stock market sector and its components.

\section{The Impact of Internationalisation on the Romanian Stock Market}

Maybe the most visible trends on the developed stock market were represented by internationalisation and globalisation. The internationalisation of a stock market refers to its capacity to integrate itself in the global network of financial transactions and stock trades. The internationalisation of a stock market allows the firms that are listed on it to get access to a broader range of financing sources and also to get access to more advance products and services. A good way to measure the internationalisation of a stock market is to account the number of foreign investors that operate on it. For example, on the Bucharest Stock Exchange in 2007 the number of foreign investors represented $40 \%$ of the total number of investors on the market. Another aspect of internationalisation is represented by the way in which stock markets from around the world interact with each other, the BSX being no exception from this rule. A good example in this case was the current financial crisis which has affected in a direct way the BSX through its relationships with outside markets and investors. As part of their anti risk strategy the foreign investors have sold their participation on the Bucharest Stock Exchange, diminishing through this their exposure on emerging markets. This action has driven the prices down far beyond the reasonable barrier. In the light of this situation the positions of the foreign investors on the Bucharest Stock Exchange has shifted from net buyers, between 2002 and 2007, to net sellers in 2008. This came as a natural consequence to the economic downturn. In 2009 however, the situation has reversed.

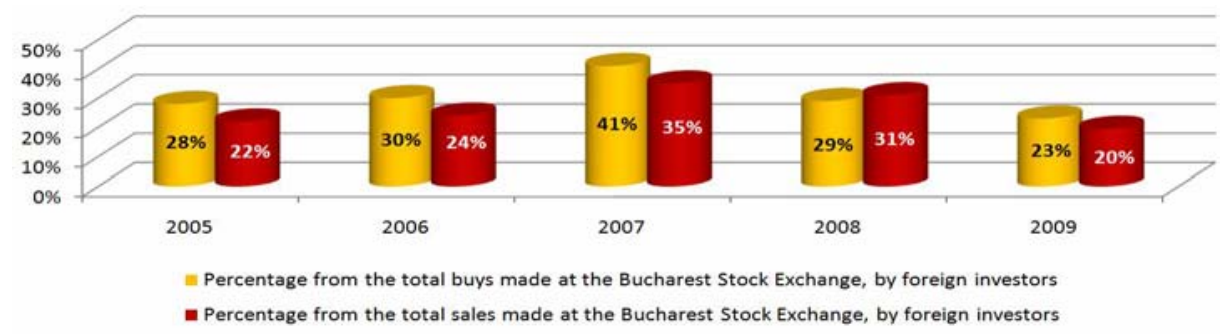

Figure. 3. The Evolution of Bucharest Stock Exchange Trades by Foreign Investors Between 2005 and 2009

Source: Intercapital Invest SA - 2009 report regarding the evolution of the Romanian stock market, at the address $\underline{\text { www.intercapital.ro }}$

5 Anghelache, Gabriela (2005), Current regulation of the stock market, Economic Publishing House, Bucharest, pp. 137 
The downfall of the Bucharest Stock Exchange was amplified by the fact that most of the local investors had speculative interests and at the first signee of trouble sold their portfolio and cashed in their investments. These premises made possible the situation were in the $3^{\text {rd }}$ quarter of 2008 for several days many top companies listed at Bucharest Stock Exchange were forbidden to trade since no offers for buying were made in the $\pm 15 \%$ margin. This lead to a historical premier on 8 of October 2008 when trading was stopped for the first time in the Bucharest Stock Exchange history. These events translated themselves in a drop in capitalisation for the Bucharest Stock Exchange from 24 billion EUR at the beginning of 2008 to 11 billion at the end of the same year. The BET index has fallen 70\% during 2008 and the BET-FI index $85 \%$, all these negative trends being related directly to the economic and financial distress that characterised the developed stock markets in 2008. The domino effect that characterised the developed stock markets from around the world didn't mist Romania, as we acknowledged earlier, the internationalisation and integration process raising its exposure to systemic risks. As a result of this, the correlation between the BET index and the other regional and international indexes has become the main factor behind the investment decisions on the Bucharest Stock Exchange and not the economic forecast or performances of the firms listed there. It became obvious that the BET index is very well correlated with the other regional indexes like the ones from Poland, Hungary or the Czech Republic, this fact being obvious also from the graphic below:

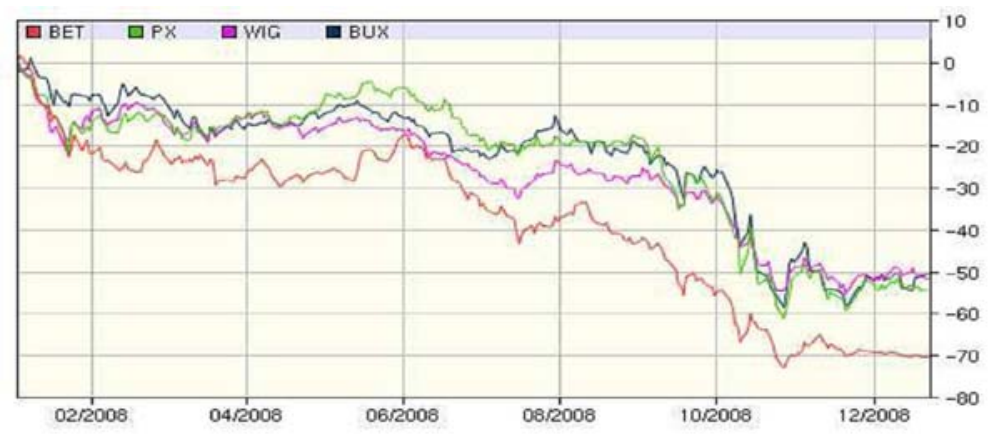

Figure. 4. The Correlation Between the Romanian Stock Market and the Other Stock Markets from the Region in 2008 (the Czech Republic, Poland, Hungary)

Source: Intercapital Invest SA - 2009 report regarding the evolution of the Romanian stock market, at the address www.intercapital.ro

It has also become obvious that the BET index had a higher raise that the other indexes in the region and also a bigger fall. This fact is due to the high volatility that characterises the Romanian stock market.

In 2009, the correlation between the BET index and the indexes from the Czech Republic, Poland and Hungary has been also strong, recording values near the ones from 2008 (0.99 between BET and PX, 0.98 with WIG and 0.97 with BUX).

The title of the BET index, as the most volatile index in the region, has been proven once more in 2009. This is evident if we compare the volatility of the BET for 2009, which was $2.58 \%$, with the one of PX $1.97 \%$, or the one of WIG $1.80 \%$ or BUX $2.30 \%$.

These facts underline the idea that the evolution of the firms listed at the Bucharest Stock Exchange had a marginal impact on the evolution of their stock prices.

\footnotetext{
6 Intercapital Invest SA - 2008 report regarding the evolution of the Romanian stock market, at the address www.intercapital.ro
} 
The conclusion is that, during instable periods, the transactions made by foreign investors and the financial climate are the determinant factors regarding the pricing of shares listed at the Bucharest Stock Exchange.

The internationalisation process that has characterised the Bucharest Stock Exchange in the last years was sparked by the fact that Romania has become a member of the European Union. This event has allowed the Romanian Stock Market to gain momentum in the context of safer investments, better regulations and better integration in the European and global financial system. Even if this are positive trends, and the stock market represented $22 \%$ of the 2007 GDP, Romania has a long way to go, even if it had to top its neighbours, with Poland stock market representing $60 \%$ of the GDP or even Hungary with a stock market that makes up for almost $37 \%$ of GDP.

As a sign of openness and internationalisation, the Bucharest Stock Exchange has developed several regional partnerships with other stock markets. So, in 2003 the Bucharest Stock Exchange has signed a partnership with the Salonika stock exchange in order to develop a segment for SME, like every developed stock market has ${ }^{7}$, this project being still in the development stage. Also, collaboration has been started in 2004 with the Vienna stock market, which has launched in 2005 in collaboration with Bucharest Stock Exchange a common index - ROTX (Romanian Trade Index). It is estimated that over 250 million EUR were invested in Romanian firms listed at Bucharest Stock Exchange as a result of the partnership with the Vienna stock market. Even if this sum may seam large, in reality is well behind the one that a working partnership may have produced over such a period of time.

\section{The Raise of Institutional Investors and its Impact on the Romanian Stock Market}

One of the most visible trends on the developed stock markets and which is also becoming more and more familiar to emerging stock market also, like Romania, is the raise of the institutional investors. Unfortunately due to deficiencies in legislation the raise of the institutional investors didn't have the hoped effect on the Romanian stock market. There are two main categories of institutional investors in Romania: the financial services firms and the open investments funds. The financial services firms represent the main institutional investors on the Romanian Stock Market. Their evolution has been solid, as a result of the vast privatisation process, started in the mid 90 , were $30 \%$ of the state firms were privatised through these financial services firms. The investment funds market is still underdeveloped in Romania, this fact being evident also from the statistics listed below:

Table No. 1. The Evolution of Mutual Investment Funds Between 2003 and 2009

\begin{tabular}{|c|c|c|c|c|c|c|c|}
\hline Country & 2003 & 2004 & 2005 & 2006 & 2007 & 2008 & 2009 \\
\hline$\overline{\mathrm{USA}}$ & 8.126 & 8.041 & 7.975 & 8.118 & 8.029 & 8.045 & 8.209 \\
\hline France & 7.902 & 7.908 & 7.758 & 8.092 & 8.243 & 8.451 & 8.038 \\
\hline Hungary & 96 & 97 & 91 & 92 & 212 & 258 & 337 \\
\hline Slovakia & 37 & 40 & 43 & 43 & 54 & 60 & 70 \\
\hline Romania & 20 & 19 & 23 & 32 & 41 & 53 & 51 \\
\hline
\end{tabular}

As we can see from the table the situation regarding the investments funds in Romania is more than grim. This is a consequence of the fact that most of the investments are done

\footnotetext{
7 Stoica, Ovidiu, The perspectives of the integration of the Romanian stock market in a single European stock market, West University Publishing House, Timisoara, 2005, pp. 295
} 
through deposits. The main factor that could contribute to the development of the investments funds in Romania and also to the development of the stock market in general are represented by: a drop in the banking interest rates (which could determine the investors to seek higher revenues in other sectors like the stock market), the raise of the average income, the reform of the pension sector, the raise of the level of financial education that each citizen is receiving and non the least the diversification and sophistication of the products and services that are available in the stock market sector.

\section{Conclusions}

In all the trends and characteristics that we have presented here, there is a certain level of interdependence and determination that allows and stimulates the interaction and integration of stock markets all around the world.

Taking into consideration the fact that, in general, the stock market is a measuring device for all social, economical and political decision and events, the state in which the Romanian stock market finds itself proves the fact that there is a long and hard way to go until the full convergence of the economy and the social-political system will be completed.

The development of new products, the extension of partnerships with other regional stock markets, doublet by a better regulatory and control system are necessary steps for the development of the Romanian stock market. But we must not forget that these are only the first ones in a long road that must be undertaken in order to integrate the Romanian stock market in the European financial main stream system.

\section{Bibliography}

1. Anghelache, Gabriela (2005), Current regulation of the stock market, Economic Publishing House, Bucharest

2. Charles Roxburgh et al. (2009), Global capital markets: entering a new era, McKinsey Global Institute

3. Ekinki, M., Kalemli-Ozcan, F., and Sorensen, B. (2007) Capital Flows within EU Countries: The Role of Institutions, Confidence and Trust, NBER International Seminar on Macroeconomics, New York;

4. Gaftoniuc, Simona (2000), International finances, Economic Publishing House, Bucharest

5. Guiso, L., Sapienza, P. and Zingales, L. (2009), Cultural Biases in Economic Exchange?, Quarterly Journal of Economics, 124 (3): 1095-1131;

6. Juvin Herve (2004), Les marches financiers, Editions d'Organisation, Paris

7. Intercapital Invest SA (2008)-Report regarding the evolution of the Romanian stock market, at the address $\underline{w w \text {. intercapital.ro }}$

8. Intercapital Invest SA (2009)-Report regarding the evolution of the Romanian stock market, at the address $\underline{w w w . i n t e r c a p i t a l . r o}$

9. Lane, P.R. (2008), EMU and Financial Integration, in: The Euro at Ten: 5th European Central Banking Conference, Lucrezia Reichlin, Ed. ECB, Brussels;

10. Liebscher K., Christl J., Mooslechner P., Ritzberger-Grünwald D. (2006), Financial Development, Integration and Stability - Evidence from Central, Eastern and South-Eastern Europe, Cheltenham, United Kingdom.

11. Portes, R. and Rey, H. (2005), The Determinants of Cross-Border Equity Flows, Journal of International Economics, 65 (2): 269-296;

12. Stoica, Ovidiu (2005), The perspectives of the integration of the Romanian stock market in a single European stock market, West University Publishing House, Timisoara

13. http://www.bvb.ro

14. http://www.finextra.com

15. http://www.efama.org

16. http://rbd.doingbusiness.ro

17. http://www.kmarket.ro 